UNTAG Law Review (ULREV)

Volume 3, Issue 1, May 2019, PP 57-70

ISSN 2549-4910 (online) \& ISSN 2579-5279 (print)

http://jurnal.untagsmg.ac.id/indeks.php/ulrev/indeks

www.fakhukum.untagsmg.ac.id

\title{
LEGAL PROTECTION FOR CONSUMERS \\ IN TRANSACTIONS FOR E-COMMERCE
}

\author{
Bing Yusuf \\ Mahasiswa Program Doktor Ilmu Hukum UNTAG Semarang \\ Email : bing.yusuf@ymail.com
}

\begin{abstract}
The development of information and electronic technology every time becomes faster, supported by the great curiosity of humans to make information technology and electronics as daily consumption. Technology penetrated into the business world pampering the community with ease of accessibility through ecommerce systems. People enjoy buying and selling facilities through e-commerce, but most people forget that every thing has a positive and negative side. The majority of people enjoy the convenience and convenience of e-commerce to access and obtain the desired items, but not a few community members have become victims of e-commerce transactions. The government acting as a regulator has issued a lot of laws and regulations, but until now all forms of injustice, fraud, and even crime through ecommerce buying and selling have not been completely blocked. Institutions established specifically to defend disadvantaged consumers also do not yet have adequate specifications to protect disadvantaged consumers through e-commerce buying and selling. The capabilities and facilities possessed by law enforcement officers are still limited, there are still many perpetrators of injustice, fraud and crime in buying and selling e-commerce that are still moving and operating freely. Based on the reality of e-commerce buying and selling formulated a problem regarding how legal protection is actually for consumers in buying and selling e-commerce? What obstacles are faced by consumers to get legal protection in buying and selling e-commerce? How is the legal effort made by consumers who are disadvantaged in buying and selling ecommerce? Using positive law analyzed with reality that occurs in the community it can be concluded that e-commerce buying and selling is arguably a new thing so that it demands for the whole legal system and legal subjects to adapt to technological developments and the progress of civilization.
\end{abstract}

Keywords : E-Commerce, Customer Legal Protection, Fraud and Crime in ECommerce Transaction 


\section{INTRODUCTION}

There is a fundamental difference between buying and selling done by e-commerce and conventionally, in conventional means buying and selling between sellers and buyers, they have to meet each other to buy and sell transactions, but in e-commerce there is no need for direct interaction between sellers and buyers. ${ }^{1}$ The interaction of buying and selling ecommerce can be done through intermediary media, namely the internet with gadgets owned by sellers and their respective buyers. But without the meeting of buyers and sellers, buying and selling transactions that are not carried out directly based on the transaction are only on trust, and buying and selling transactions conducted on the basis of trust tend to be more risky than direct buying and selling transactions, therefore fraud or frequent Buyer dissatisfaction with transactions through e-commerce, because in the process of buying and selling ecommerce everything is done digitally.g and selling activities through e-commerce.

The development of technology, and the change in the way people do buying and selling activities make law as the guardian of order and order in society must be fast following the increasingly rapid dynamics of society in the presence of technology. As stated by Satjipto Raharjo in his book entitled Law and Social Change, he stated that the law follows changes in society, so the law must be careful in following changes in society, therefore the Indonesian government issues legislation -direction from the Dutch Colonial Bedrijfsreglementerings Ordonnantie in 1934. The Law is Law no. 7 of 2014 concerning Trade which came into force on March 11, 2014, and even there are laws which specifically regulate crimes committed through digital media (Cyber), namely Law no. 19 of 2016 jo. Law no. 11 of 2008 concerning Information and Electronic Transactions.

The existence of various juridical provisions governing e-commerce processes should provide a sense of security when conducting transactions in e-commerce activities. Juridical provisions should be able to provide legal certainty for parties conducting e-commerce activities. But the reality is not the case. There are still many frauds and violations of law committed by one party which then harm the other party in an e-commerce transaction. Forms of cheating or violations of the law can be in the form of forgery (forgery of digital documents), fraud, and so forth.

There are so many consumers who have suffered losses due to e-commerce buying and selling due to irresponsible sellers or indeed have the intention to cheat from the moment the transaction has not occurred. With the existence of e-commerce convenience and accessibility of a product for consumers to be increased, but the buyer and seller do not meet directly, the

1 Watson, Peter. Ideas: A History of Thought and Invention, From Fire to Freud by Peter Watson. Harper Perrenial, Broadway, New York. 2005. Hlm 25. 
buyer does not identify the product that is interested directly, the seller also does not know the identity of the buyer, this is vulnerable resulting in one party who were disadvantaged in the implementation of e-commerce transactions, therefore it is very important that legal certainty can be used as a safeguard for both parties to the transaction. Since 1999, Law no. 8 of 1999 concerning Consumer Protection (UUPK) which generally regulates and protects consumer rights covering broad transactions, but has not been able to guarantee overall legal certainty in e-commerce transactions. ${ }^{2}$ So that the government then enacted Law No. 19 of 2016 jo. Law no. 11 of 2008 concerning Information and Electronic Transactions (UUITE).

Based on the reasons above, in this study will be focused in depth the legal protection for consumers in the sale and purchase transactions conducted by e-commerce viewed from the side of civil agreement contained in the Civil Code (KUHPerdata) ${ }^{3}$ which is also a regulation originating from The Dutch colonial period, known as Burgerlijk Wetboek Voor Indonesie as the basic principles in conducting buying and selling transactions, was then analyzed more specifically by using UUPK and UUITE by using an example of a case that often occurs in ecommerce transactions, therefore research This is titled "LEGAL PROTECTION FOR CONSUMERS IN E-COMMERCE BUYTRANSACTIONS".

The research's objectives are to understand the forms of legal protection for consumers in ecommerce buying and selling transactions. Learning the obstacles faced by consumers to get legal protection in e-commerce buying and selling transactions. Identifying the legal efforts made by consumers who are harmed by e-commerce buying and selling transactions.

\section{DISCUSSIONAND ANALYSIS}

\section{Forms of legal protection for consumers in e-commerce buying and selling transactions.}

Legal protection for consumers in e-commerce transactions arises when there is a transaction where the consumer begins to provide payments or is usually done by transferring some money to the account provided by the seller. In reality there are still many consumers who do not know that their rights are protected by law in online buying and selling transactions. Consumers must have a basic understanding that their rights are protected by Article 4 of UUPK so that consumers in buying and selling e-commerce can feel safer when making transactions. Article 4 UUPK states that consumer rights in the sale and purchase agreement are: ${ }^{4}$

1. The right of comfort, security and safety in consuming goods and / or services.

2. The right to choose goods and / or services and obtain said goods and / or services in

2 Kristiyanti, Celina Tri Siwi. Hukum Perlindungan Konsumen Cetakan kelima. Sinar Grafika, Jakarta. 2016.

3 Subekti, Raden. Kitab Undang-undang Hukum Perdata. Pradnya Paramita, Jakarta. 2004.

4 Miru, Ahmadi; Yodo, Sutarman. Hukum Perlindungan Konsumen Edisi Revisi. RajaGrafindo Persada, Jakarta. 2015. 
accordance with the exchange rate and conditions and guarantees promised.

3. Right to get information that is correct, clear and honest regarding the condition and guarantee of goods and/ or services.

4. The right to be heard opinions and complaints about the goods and / or services used.

5. Right to get advocacy, protection, and efforts to properly resolve consumer protection disputes.

6. Right to get consumer guidance and education.

7. The right to be treated or served properly and honestly and not discriminatory.

8. The right to obtain compensation, compensation and / or reimbursement, if the goods and / or services received are not in accordance with the agreement or not as they should.

9. Rights stipulated in the provisions of other laws and regulations.

In buying and selling transactions conducted through intermediary facilities it does have weaknesses that do not often occur in the case of conventional buying and selling, in conventional buying and selling sellers and buyers meet in real world, real time condition (real time and space dimensions). Buying and selling transactions are carried out directly where after the buyer hands over the money then the seller immediately submits the item and is received by the buyer or vice versa almost never happens which is called a default unless the sale and purchase is done by means of credit. Default is the existence of a party that is harmed in an agreement if one of the parties bound to the agreement does not fulfill its obligations or is not on time in fulfilling its obligations. The agreement in it is determined by the maturity date, it can be said as default if one of the parties has not fulfilled its obligation after passing the specified date. Actually there are three possibilities that can occur so that a default occurs in an agreement:

1. One party does not fulfill the performance

2. One party is late in fulfilling an achievement

3. One party achieves not as it should

Every three of the above contains elements of achievement. Achievement is an obligation that must be fulfilled by the party to say he has done the part that must be done to fulfill his part in an agreement.

Civilly in an agreement agreement, defaults have an impact where the party that has not made an achievement must compensate. Losses in default are losses that are actually suffered by one 
party. In the civil provisions of article 1243 and 1244 of the Civil Code, compensation in it includes reimbursement (costen), loss (scaden), and interest (interest). ${ }^{5}$ All compensation can be excluded as explained in Article 1245 conditioned if the party who has not fulfilled his achievement is due to overmacht, or force majeure known in Indonesian as a condition that forces one party to fail to fulfill its performance. However, it does not mean that it has been completed and the parties that have not fulfilled their achievements are free from their obligations, there will only be an extension of time to fulfill obligations to other parties.

Actually, almost the same legal concept is between agreements and buying and selling transactions through e-commerce. It's just that the difference in agreements that occur in ecommerce trading is done through intermediary facilities and does not occur in real world, real time condition (real time and space dimensions), but through cyberspace and different time dimensions. Still, the concept of electronic transactions adhering to the basis of the Agreement Law is mainly focused on agreements.

In the agreement law, an agreement occurs if both parties who will transact state the ability and agreement in the contents of the agreement. It is stated in Article 1320 of the Civil Code which consists of: ${ }^{6}$

1. Agreement of the parties (Consensus)

The agreement is the agreement of both parties regarding the clauses in an agreement.

2. Skills for making agreements (Bekwaan)

Skills are regulated according to law in Article 330 of the Civil Code with an explanation that skills are measured if the agreement maker is more than 21 years old or can be less than 21 years old but is married and psychologically healthy.

3. Acertain thing

A certain thing regulates an object or something that is promised. An object of agreement must be clearly determined by the parties, can be either goods or services or even do nothing, now there are even objects of agreement that are not tangible.

4. A legal cause

Because the halal has a broad scope where in essence everything that is promised must not conflict with the laws and regulations, public order, and morality.

There are only differences in writing between the legal requirements of the agreement and the legitimate sale and purchase transactions conducted through electronic media which are

5 Raharjo, Handri. Hukum Perjanjian di Indonesia. Pustaka Yustisia, Jakarta. 2009

6 Salim, H.S. Hukum Kontrak Teori dan Teknik Penyusunan Kontrak. Sinar Grafika, Jakarta. 2003. 
contained in article 47 paragraph 2 of the Government Regulation of the Republic of Indonesia No.82 of 2012 concerning Implementation of Electronic Transactions and Systems (PP PSTE), namely:

1. There is agreement between the parties.

2. Performed by legal subjects who are competent or who are authorized to represent in accordance with the provisions of the legislation.

3. There are certain things.

4. The object of the transaction may not conflict with the laws and regulations, decency and public order.

Table 1 : Legal Requirements for Agreement and Electronic

Agreement

\begin{tabular}{|c|c|}
\hline $\begin{array}{c}\text { Requirements of an } \\
\text { Agreement to be Legal } \\
\text { Agreement of paerties (Consensus) }\end{array}$ & $\begin{array}{l}\text { Requirements of an Electronic } \\
\text { Agreement to be Legal } \\
\text { Agreements between parties }\end{array}$ \\
\hline $\begin{array}{l}\text { Capabilities to make } \\
\text { an agreement } \\
\text { ( Bekwaan) }\end{array}$ & $\begin{array}{l}\text { Performed by legal subjects } \\
\text { who are competent or who are } \\
\text { authorized to represent } \\
\text { in accordance with the provisions } \\
\text { of the legislation. }\end{array}$ \\
\hline A certain thing & Certain things \\
\hline A legal cause & $\begin{array}{l}\text { The object of the transaction may not } \\
\text { conflict with the laws and regulations, } \\
\text { decency and public order. }\end{array}$ \\
\hline
\end{tabular}

Source: The composition of the author based on the Civil Code and PP PSTE

\section{Constraints faced by consumers to get legal protection in e-commerce buying and selling transactions.}

The frequency of cases in buying and selling carried out through many e-commerce facilities is actually detrimental to the buyer rather than the seller, this is due to the average loss experienced by the seller because the buyer does not provide a clear address or accurate address that allows mistakes or errors in sending goods that harm the seller.

In terms of buyers, buyers have many weaknesses in buying and selling conducted through e- 
commerce facilities, ambiguity and uncertainty over security and assurance that buyers will receive correctly and completely the goods sold by sellers in the sale and purchase made through e-commerce facilities. ${ }^{7}$

Many examples of cases that often occur around us are the losses experienced by buyers in buying and selling that are done through e-commerce facilities which among them are caused by things like:

1. The buyer fulfills his performance first

Buying and selling through e-commerce facilities systematically requires consumers to make their achievements first by making a payment by transferring a certain amount of funds to an account given by the seller even though the buyer has not seen the goods directly purchased, so that in this position a number of funds have been transferred to the seller's account, the position of the buyer in the agreement becomes vulnerable or can be said to be weak because the buyer must wait for the seller to fulfill his performance.

2. There is no price negotiation in the agreement between the seller and the buyer.

Buying and selling that is done through e-commerce facilities occurs without a meeting between the party that sells the goods and prospective consumers or buyers who want to buy goods. Different conditions and situations with conventional buying and selling where the seller and buyer meet directly for the buyer to see firsthand the details of the goods being sold and the seller conveys the price of the goods sold, then the negotiation process takes place, namely bargaining between the seller and buyer, if there is a meeting between the price desired by the buyer and the seller then an agreement occurs. In buying and selling done through e-commerce facilities, buyers can only see the price written by the seller in the sales facility used by the seller to sell the goods, so it is not possible to bargain unless the sale and purchase through e-commerce facilities is limited to buyers. identify the item and then the buyer meets the seller directly and negotiates the price.

3. Certainty and authenticity of information received by buyers in buying and selling conducted through e-commerce facilities.

There is no guarantee that the information provided by the seller is original information, even very possible in many cases that occur in buying and selling that is done through ecommerce facilities where all information used by the seller including the seller's own identity is also false. It can be said that consumers who intend to buy products or goods offered through buying and selling done through e-commerce facilities are valid legal subjects, because after the buyer agrees to buy goods offered by the seller, then the seller

7 Gao, Jerry. Introduction to E-Commerce. Computer, Information, \& System Engineering Journal. CISE, Cincinnati, Ohio. 1999. 
provides an account number where the buyer must transfer some funds into the account. In a case like this the buyer is not in good faith, but the buyer cannot ensure that the identity and existence of the seller as the other party in the legal subject of sale and purchase is correct.

As explained above, many types of cases that are possible to occur in buying and selling are carried out through e-commerce facilities. Although the UUPK from Article 8 to Article 16 has been comprehensively regulated until the prohibition on buying and selling.

Article 8 of the UUPK states that the seller is prohibited from selling items that are included in the following criteria:

1. Not fulfilling or not in accordance with the standards required by statutory provisions.

2. Not in accordance with the net in the amount and count stated on the item label.

3. Not according to the size, size, scale and number in the calculation according to the actual size.

4. Not in accordance with the conditions, guarantees, privileges or efficacy as stated in the label, etiquette, or description of goods and / or services.

5. Not in accordance with the quality, level, composition, processing, style, mode, or certain usage as stated in the label or description of goods and / or services.

6. Not in accordance with the promises stated in the label, etiquette, statement, advertisement or promotion of the sale of the goods and / or services.

7. Does not include the expiration date or the best use / utilization period for the item.

8. Not following the provisions of producing halally, as in the "halal" statement stated in the table.

9. Do not put labels or make an explanation of the goods containing the name of the item, size, net weight / content, composition, rules of use for the date of manufacture, side effects, names and addresses of business actors and other information for use which must be made.

10.Does not include information and / or instructions for using goods in the Indonesian language in accordance with applicable laws and regulations.

In addition to the aforementioned matters, there are also further provisions in article 8 paragraph 2 to paragraph 4 of the UUPK which explain violations and sanctions that can be imposed if the seller violates the prohibition, namely the prohibition to trade damaged, defective or used and contaminated goods without providing information complete information about the item in question. The seller must guarantee that there are no hidden 
defects in the goods sold or there is a shortage of items sold and unknown to the buyer, but the seller does not explain it when offering the item. Sanctions that can be imposed are prohibitions to trade goods and services and the seller is obliged to withdraw what he has sold from circulation.

Article 9 UUPK prohibits sellers from trading merchandise that contains elements of manipulation to deceive prospective buyers or consumers so that buyers or prospective consumers think that the goods sold by the seller have special advantages or specifications that the item does not actually have. Misleading information carried out by sellers who do not intend to deceive consumers is explained in article 10 of the UUPK which categorizes it into 5 groups:

1. Price or tariff for an item and / or service

2. Use of an item and / or service

3. Conditions, dependents, guarantees, rights to compensation for an item and / or service

4. Offer discounts or attractive prizes offered

5. Danger of using goods and / or services

So if the buyer still keeps the data that deals with buying and selling conducted through ecommerce facilities carried out by the buyer, the buyer is said to have legal evidence. Evidence from buying and selling done through e-commerce facilities can be in the form of e-mails, proof of records, proof of web pages where buyers buy goods, and proof of transfer of funds used by buyers to pay for goods purchased. However, even though the buyer already has legal evidence, the buyer still cannot get justice if the seller has an unknown identity and presence. Buyers can carry out the process specified in the Procedure Law, where the buyer reports the occurrence of losses suffered by the buyer because of the sale and purchase made through ecommerce facilities to law enforcement officials by including evidence as mentioned earlier in the form of printouts (print-outs). Law enforcement will then investigate to take action against cases reported by buyers by tracking the presence and identity of the seller. This is where more and more obstacles arise. The following are possible obstacles: ${ }^{8}$

1. If the seller who has the intention not to use fake identity and fake internet protocol address.

2. If the seller who has a bad intention has removed his footprint by removing the web page and internet protocol address after a transaction by the buyer.

3. If the seller's position is outside the territory of the jurisdiction of Indonesia where there are no bilateral agreements between countries namely extradition.

8 Barling, Chris; Townsend, Bruce. Selling Successfully Online Over 120 Top Tips for Running an Ecommerce Web Site. Actinic Sorftware Ltd, Surrey. 2008. 


\section{Legal efforts carried out by consumers who were harmed by e-commerce buying and selling transactions.}

In 2008 the government promulgated specific regulations governing the activities of all Indonesian people engaged in cyberspace through information technology facilities. The said law is Law no. 11 of 2008 concerning Information and Electronic Transactions (UUITE). In UUITE, it is explained in full about the obligations and rights of each party related to buying and selling activities carried out through e-commerce facilities, in this case, sellers who offer their goods through e-commerce facilities, and buyers who intend to purchase goods through facilities. e-commerce. Even though Article 8 and Article 16 of the UUITE have also been explained in detail the prohibitions that must be avoided by sellers when conducting buying and selling activities conducted through e-commerce facilities, but have not been able to provide legal certainty for buyers, because even after UUITE in 2008 promulgated there are still many legal cases related to electronic transactions.

In 2012 the Indonesian government issued Government Regulation no. 82 of 2012 concerning the Implementation of Systems and Electronic Transactions. PP PSTE increasingly specifies the coverage of the elements included and used in buying and selling activities carried out through e-commerce facilities. ${ }^{9}$ PP PSTE also added several things that contained activities that were prohibited for individuals in carrying out transactions through electronic systems. The existence of PP PSTE has also not been able to optimally stem the occurrence of legal cases in buying and selling activities carried out through e-commerce facilities, but precisely some new systems adapted from level chain management increasingly add variants and types of fraud and fraud in activities buying and selling is done through e-commerce facilities.

Just last year, in 2016 the government added and revised several articles contained in the UUITE, contained in Law no. 19 of 2016 concerning Amendments to Law Number 11 Year 2008 concerning Information and Electronic Transactions. Until now the Law is still running to complement the 2008 UUITE. More and more restrictions relating to activities through electronic facilities and digital media are regulated in UUITE 2016. Until now the effectiveness of UUITE 2016 continues to be monitored, but still there are still many legal cases related to buying and selling activities carried out through e-commerce facilities.

All of the above laws and regulations can be the basis for legal efforts by buyers in buying and selling activities carried out through e-commerce facilities that feel their rights are harmed. ${ }^{10}$ Alternative legal remedies that can be carried out by buyers who experience losses after undergoing buying and selling activities conducted through e-commerce facilities are:

9 Wesseler,Marcelo. Indonesia's eCommerce Landscape 2014: Insights into One f Asia Pacific's Fastest Growing Markets. SP eCommerce, Singapore Post, Singapore. 2014.

10 Ward, Theresa. Strategies for Reducing the Risk of e Commerce Fraud. First Data, Colorado. 2010. 


\section{Report to law enforcement officials}

The buyer can report any losses suffered by him after making a purchase made through an ecommerce facility by including print-out evidence from electronic documents related to the purchase and proof of payment made by the buyer. Based on article article 5 paragraph 1 of the UUITE which explains that electronic information and / or electronic documents and / or their printouts are legal legal evidence. Buyers can also include other evidence such as letters, short message service (SMS), proof of conversation between sellers and buyers in social media facilities, e-mail, and so on. Then it becomes the obligation of law enforcement officials to try to track and identify the perpetrators who caused losses in buying and selling activities carried out through e-commerce facilities. Conditioned by law enforcers can identify and arrest the perpetrators, then the law enforcement process will be carried out as enacted in the Criminal Procedure Code, or the Civil Procedure Code if the lawsuit is filed by the buyer based on the default made by the seller in buying and selling activities carried out through e-commerce facilities.

\section{Dispute resolution through Alternative Dispute Resolution(ADR)}

Alternative Dispute Resolution (ADR) is a dispute resolution that is not carried out through a litigation process (dispute resolution through a court process) but non litigation is the implementation of dispute resolution through an out-of-court process by individuals or institutions that have certification to run ADR. ${ }^{11}$

ADR according to Law no. 30 of 1999 concerning Arbitration and Alternative Dispute Settlement described as an institution for resolving disputes outside the court based on the agreement of the parties to the exclusion of litigation dispute resolution in court.

There are several types of ADR or settlement of disputes outside the court, namely:
a. Consultation Institution;
b. Negotiating Institutions;
c. Mediation Institutions;
d. Conciliation Institution;
e. Expert Appraisal;

For consumers who are harmed not because of fraud or the presence of bad faith from the seller in buying and selling activities carried out through e-commerce facilities, it is better to take ADR through mediation if both parties that conduct buying and selling activities conducted

11 Nugroho, Susanti Adi. Mediasi Sebagai Alternatif Penyelesaian Sengketa. Telaga Ilmu Indonesia, Jakarta. 2011. 
through e-commerce facilities agree. Based on Article 47 of the UUPK which states that consumer dispute resolution outside the court is held to reach an agreement on the form and amount of compensation and / or regarding certain actions to guarantee that the loss will not occur again or the consumer will suffer a loss again. It is hoped that by conducting mediation a win-win solution will occur where no party is harmed because basically the principle of mediation is to find a meeting point of agreement for each party to resolve the dispute. So mediation is the most suitable ADR to do if there is a dispute related to buying and selling activities carried out through e-commerce facilities.

\section{Settlement of disputes through the Consumer Dispute Settlement Agency.}

Based on the explanation of article 49 paragraph 1 of the UUPK where it is said that BPSK is formed by the government in the Level II Region to resolve consumer disputes outside the court. BPSK was established to provide legal assistance to consumers or in this case buyers who make purchases through e-commerce facilities. BPSK can provide legal assistance to buyers who make purchases through e-commerce facilities through a process of mediation, arbitration and conciliation. Buyers who make purchases through e-commerce facilities can also get consultations in terms of consumer protection. BPSK also helps to report to general investigators if there are violations in buying and selling activities carried out through ecommerce facilities. BPSK can also help to call bringing the seller who has harmed the buyer to be able to resolve the dispute with the buyer with the help of investigators and expert witnesses. Even BPSK has the authority to impose administrative sanctions on sellers who conduct buying and selling activities conducted through e-commerce facilities.

\section{CONCLUSION}

The existence of buying and selling transactions conducted through e-commerce facilities arises because of the encouragement to develop from the community with the advancement of technology. Everyone wants more easy access to get the desired items, but behind that convenience there is a shortage where security and legal certainty from the side of the buyer or consumer cannot be guaranteed in the process of buying and selling carried out through ecommerce facilities. Consumers who have agreed to and conducted transactions to carry out their achievements by transferring a number of funds to the seller's account have a vulnerable position to be harmed because with indirect transactions but through the media it becomes difficult to understand and guarantee authenticity and certainty the buyer can get the goods he wants.

The government prepares the regulations contained in UUPK, UUITE, PP PSTE, equipped with several other regulations that have relevance to buying and selling transactions conducted through e-commerce facilities. The existence of good and complete regulations to become the 
legal basis equipped with the cooperation between BPSK and law enforcement officers should make the legal certainty of consumers buying and selling transactions using e-commerce facilities guaranteed, but not so.

Until now there are still many cases of disputes among consumers who have been harmed through buying and selling e-commerce. According to Schuit in a book written by Sidharta, law enforcement cannot be separated from the attachment of the legal system. The legal system consists of 3 elements that are interrelated and have their respective roles.

\section{RECCOMENDATION}

The government must begin to impose administrative regulations and require ownership of permits to make buying and selling conducted through e-commerce facilities.

Establish special supervisory institutions to accommodate and supervise and access ecommerce activities consisting of members who have specific experience and specifications in the field of information technology, or information systems and electronic transactions.

Consumers are encouraged to choose a platform or organizer of buying and selling through a well-known or official e-commerce facility and can be trusted with a standard guaranteeing the accessibility of contact with the seller and guarantee that there will be follow-up from the seller if there is a discrepancy.

Every time a transaction is carried out, the consumer should save and print out any details relating to purchases made through e-commerce facilities.

\section{REFFERENCES}

Barling, Chris; Townsend, Bruce. Selling Successfully Online Over 120 Top Tips for Running an Ecommerce Web Site. Actinic Sorftware Ltd, Surrey. 2008.

Gao, Jerry. Introduction to E-Commerce. Computer, Information, \& System Engineering Journal. CISE, Cincinnati, Ohio. 1999.

Hussain, Mohhamed Ali. A Study of Information Security in E-Commerce Applications, Intenrational Journal of Computer Engineering Science (IJCES). KL University, Guntur. 2013.

Kristiyanti, Celina Tri Siwi. Hukum Perlindungan Konsumen Cetakan kelima. Sinar Grafika, Jakarta. 2016.

Miru, Ahmadi; Yodo, Sutarman. Hukum Perlindungan Konsumen Edisi Revisi. RajaGrafindo Persada, Jakarta. 2015. 
Nugroho, Susanti Adi. Mediasi Sebagai Alternatif Penyelesaian Sengketa. Telaga Ilmu Indonesia, Jakarta. 2011.

Raharjo, Handri. Hukum Perjanjian di Indonesia. Pustaka Yustisia, Jakarta. 2009

Salim, H.S. Hukum Kontrak Teori dan Teknik Penyusunan Kontrak. Sinar Grafika, Jakarta. 2003.Subekti, Raden. Kitab Undang-undang Hukum Perdata. Pradnya Paramita, Jakarta. 2004.

Suryana. Metodologi Penelitian Model Praktis Penelitian Kuantitatif dan Kualitatif. UPI, Bandung. 2010.

Ward, Theresa. Strategies for Reducing the Risk of eCommerce Fraud. First Data, Colorado. 2010.

Watson, Peter. Ideas: A History of Thought and Invention, From Fire to Freud by Peter Watson. Harper Perrenial, Broadway, New York. 2005.

Wesseler,Marcelo. Indonesia's e Commerce Landscape 2014: Insights into One f Asia Pacific's Fastest Growing Markets. SPeCommerce, Singapore Post, Singapore. 2014. 